\title{
Is medicolegal work a duty?
}

\section{R J Leitch}

It is

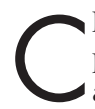
linical situations leading to complaints are increasing in frequency and it is important that they are handled in a fair and open way. Many complaints can be resolved locally; however, where there has been a perceived adverse outcome legal advice may be sought. Advocates protecting the rights of patients will seek expert opinion to guide them. Frequently these cases are complex and outcomes are not ideal. Patients and their families may have suffered a great deal.

The role of the expert is to identify what has happened and to interpret events and pathology so that all involved can follow them. The responsibility of the expert is to the court. However, this does not mean that all experts will agree. Increasingly, procedure rules stipulate how experts and assessors should produce their opinion and evidence. ${ }^{1}$ Guidelines on the responsibilities of experts and the opportunity for experts to discuss clinical issues, to produce an agreed opinion to the court, is now mandatory. Where opinion is not agreed, clear reasons need to be explained.

Legal work is of importance both from the position of the claimant and from the position of the medical profession. Legal cases can be high profile and represent areas of practice where the profession is open to public scrutiny. The role of the expert in providing sound opinions and their ability to express their opinions with clarity to claimants and to the legal profession is paramount.

Studying cases where legal action is being taken enhances one's clinical experience by providing time to study adverse clinical incidents or where situations have been perceived by the claimant as adverse. This allows one to be aware of potential risk management issues within one's own practice and organisation. A pragmatic approach is required to protect against paranoia.

The practice of medicine means that one is offering opinion on a daily basis. In areas of specific interest one becomes "expert" and colleagues and patients will seek opinions within this area. The legal profession require expert medical opinion when approached by an aggrieved claimant and should be provided with such opinion. The profession should not fear this situation but rise to the challenge, seeking to educate and explain the frequently complex situations that arise.

Participating in this process is likely to become integral to modern medicine, if it is not already. Some clinicians will have more interest in this type of work than others; however, the profession as a whole needs to acknowledge that the provision of expert opinion is an important area in which skills need to be developed or learned. Who makes the best expert is interesting-is it the most experienced, the most reasoned, or the most erudite? I quote the opinion of Paracelsus ${ }^{2}$ on the nature of a doctor, "If your heart is false, you will also be a false physician; if your heart is just, you will also be a true physician." This can be applied to the role of the expert witness as well as the physician. If one carries the same qualities from clinical work to the expert role, knowledge itself is not all important; however, the desire to be just in the application of knowledge is a legitimate aim.

Remuneration for expert opinion is not comparable with time spent developing a busy private practice within ophthalmology. It is my opinion, however, that if one does not charge a comparable fee to legal professionals one is not treating professional skills and knowledge with appropriate respect. If we do not respect our profession can we expect this of others?

If the role of expert is done well and with sincerity there should be little opportunity for public humiliation in court and a badgering barrister will only make himself look foolish.

Br J Ophthalmol 2003;87:383

\section{Author's affiliations}

R J Leitch, Epsom and St Helier NHS Trust, UK; rilhome@dircon.co.uk

\section{REFERENCES}

1 Civil Procedure Rules. Part 35. Experts and assessors. January 2002.

2 Jacobi J, ed. Paracelsus selected writings.

Princeton, NJ: Princeton University Press 1979

\section{Is medicolegal work a duty?}

\section{Taylor}

It is not

W ith the amount of money spent on settling medicolegal claims by the National Health Service in the United Kingdom soaring, should all ophthalmologists join the fray and give their advice to the courts? The increase in medical litigation is a worldwide phenomenon but with huge differences between countries in the value and frequency of settlements.
It is sometimes suggested that it is a duty of every ophthalmologist to give advice on medicolegal cases in order to help the courts operate efficiently and fairly, and most especially pressure is put on distinguished ophthalmologists to take on the work, as their specialist opinion is particularly valuable.

But is it really a duty and should we feel in any way compelled to take on this work? I will argue that it is not a duty, that it distracts us from our main work, and that we should not normally take it on.

Why do we take on medicolegal work anyway? There are three main reasons.

Firstly, it is a duty to colleagues, to the court, and to the running of the legal system: is the path of duty the way to glory?

The Oxford English Dictionary defines a duty as an "Action, or an act, that is due by moral or legal obligation; that which one ought or is bound to do." That a sense of duty is widespread and powerful cannot be doubted. Saki wisely observed "people will do things from a sense of duty which they would never attempt as a pleasure." Virtually everyone has a sense of duty: it is its intensity that is so very variable. 
Perhaps one gets an insight into why a sense of duty varies so by looking at some of the synonyms for duty: obligation, onus, liability, responsibility, the right thing. They mostly convey a feeling of tediousness that has never been popular and cannot be an obligation in life. Are people who do things as a duty any better than those who do them for more pragmatic reasons? "When a stupid man is doing something he is ashamed of, he always declares that it is his duty." Well, George Bernard Shaw may not have been right always, but in this respect maybe he has hit the nail on the head. Perhaps we are ashamed of doing medicolegal work. It is not necessarily the best of the profession that involve themselves in the business, the academic exercises that are indulged in are of more legal than scientific or medical interest and it is not instructive in any way that is of help to patients who we profess to serve.

Why should we, out of a sense of duty, take part in the adversarial antics that barristers still get up to in court? Despite Lord Woolf's reforms, there is still an unnecessarily adversarial atmosphere in court. The formality of court proceedings may be necessary to the dignity and smooth running of the legal process, but the dress, some of the arcane practice, and the language are intimidating and unhelpful.

Secondly, it is interesting and professionally challenging. A number of ophthalmologists like dressing up and taking part in the court drama; they wear a snappier suit than is their normal attire, don a tasteful tie, and enjoy the challenge of giving clear and helpful advice to the court, sometimes bravely facing a challenge from the barrister for the other side. Oh yes, there are two sides in every court, despite attempts to get a nonadversarial ambience in the courtroom.

Lord Justice Wall said "The idea that appearances in court are some kind of gladiatorial combat where the naked doctor armed only with net and trident is torn to pieces by the legal lions waving machetes whilst the judge smilingly gives the thumbs down-these ideas ought to have gone." They ought to have gone ages ago but they have not. Efforts are being made by judges to address these issues, but as the noted judges, Butler-Sloss and Hall wrote "Yet many doctors still see the courtroom as a hostile environment, and some perceive the purpose of cross examination as being to impugn their professional integrity by a personal attack on their credibility." I am sure that Butler-Sloss would not let cross examination get out of hand in a court where she is judge, but I suggest that in practice she is in the minority.

But we are doctors, not lawyers, and the professional activity that goes on in court has very little to do with our day to day professional work, and despite the public rantings of a few lawyers that the courts will change (improve) the way we practise and protect patients, I don't think that a court has much influence over current medical practice and it never will do. It is sometimes not the best ophthalmologists that take part and there is little to learn from reading even the most expert of expert medical reports because they are often based not on current thinking but that at the time of the act that has brought about the legal action. With the delay in the legal system, this can be many years!

Why do the courts accept the evidence of less than top drawer experts as readily as that from the best? It is, surely, because they do not know the difference.

Medicolegal activity, being less than at the pinnacle of professional activity, also affects lawyers: why does the legal profession have difficulty in recruiting top drawer judges if it is so important that the best of the professions take part in medicolegal work?

Thirdly, we do it for the money. Fees as an expert witness are useful if not excessive and are particularly helpful to ophthalmologists who live in a part of the country where private practice is scarce. There is now such a demand for advice that even consultants of just a few months' standing are sought for their advice and this continues until well after retirement. It is not unusual to find an expert witness giving the court advice on an operation or procedure that he has not performed for years, even though he might have done so with aplomb when professionally active. But is it right to do this work primarily for the money? I am not saying that it is not OK to work for money-who doesn't? But we can do better elsewhere: in private practice or by doing waiting list initiatives or other mainstream NHS work. Also, the time spent on medicolegal work reduces the ophthalmologist's ability to improve his chances in the lottery of professional, and therefore financial, advancement in discretionary points and distinction awards (for the uninitiated these are arcane mechanisms for rewarding the lucky few in the NHS). It is well known that there is a minority of doctors who spend disproportionate amounts of time on legal work to the detriment of their professional reputation within the medical community, even if not in the legal world-in which area would most ophthalmologists rather be respected?

Why then, if our advice on which the case often hinges is so valuable, do the medical experts receive so much less than the barrister, and why are we apparently more subject to the whim of the taxing master and solicitors as to payment and cancellation fees?

Perhaps a way out of this is to encourage a cadre of ophthalmologists to take the matter seriously, perhaps have a medicolegal society with an entrance examination. The ophthalmologists involved need not be the most expert clinically or academically but they might train themselves to avoid the pitfalls that await the less than expert expert. ${ }^{2}$

Br J Ophthalmol 2003;87:383-384

\section{Author's affiliations}

D Taylor, Visual Sciences Unit, Institute of Child Health, 10 Guilford Street, London WC1N 1EH, UK; d.taylor@ich.ucl.ac.uk

\section{REFERENCES}

1 Butler-Sloss E, Hall A, Expert witnesses, courts and the law. J Roy Soc Med 2002;95:431-4.

2 Williams $C$. The role of the expert witness. Arch Dis Child 2002;87:267-8. 